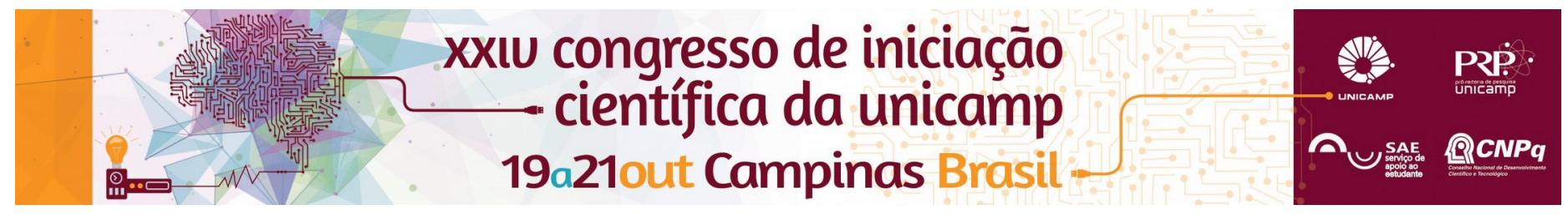

\title{
Impactos da instalação da Faculdade de Ciências Aplicadas da UNICAMP, em Limeira/SP - percepção da população do entorno.
}

\section{Murilo Silva* (Bolsista SAE/UNICAMP), Prof. Dr. Álvaro D'Antona (Orientador), FCA/UNICAMP.}

\section{Resumo}

O objetivo deste trabalho foi identificar quais os impactos causados pela instalação da Faculdade de Ciências Aplicadas da UNICAMP na percepção da população dos bairros Jardim Morro Azul e Jardim Paulista da cidade de Limeira/SP.

\section{Palavras-chave:}

Políticas Públicas, Ensino Superior, Impactos Locais.

\section{Introdução}

Atualmente a Faculdade de Ciências Aplicadas da Unicamp está no seu oitavo ano de funcionamento e não havia estudos que avaliassem qual foi o impacto de sua instalação para a população do seu entorno'.

Neste trabalho buscou-se identificar de que forma a instalação do campus da Faculdade veio a causar possíveis consequências não-intencionais para a população que não é direta e imediatamente beneficiada com vagas na Universidade.

As hipóteses iniciais desta pesquisa, eram de que dentre os possíveis impactos da instalação da FCA/UNICAMP estavam: o aumento do custo de vida na região do entorno do campus (aluguéis, supermercados, lojas), o aumento da criminalidade (furtos e roubos) e o aumento dos ruídos (barulhos de festas de estudantes).

Foram realizadas entrevistas com 21 moradores dos bairros Jardim Morro Azul e Jardim Paulista, residentes na região há no mínimo 7 anos. A coleta de dados ocorreu entre novembro/2015 e fevereiro/2016, na qual foi utilizado um questionário semiestruturado, com perguntas abertas de opinião e percepção.

A pesquisa foi submetida e aprovada pelo Comitê de Ética em Pesquisa da Universidade Estadual de Campinas, com CAAE no 45987315.3.0000.5404.

\section{Resultados e Discussão}

Para $57,1 \%$ (12) dos entrevistados, a simples ocupação do terreno onde foi construída a Faculdade já foi algo positivo, pois no local existia um canavial, com muito mato e uma grande quantidade de lixo.

Quando questionados sobre o custo de vida no bairro, $47,6 \%$ (10) responderam que é mais caro em relação a outros bairros/aumentou nos últimos anos; $42,9 \%$ (9) disseram que o custo de vida é semelhante ao de outros bairros; $9,5 \%$ (2) responderam que é mais barato/diminuiu nos últimos anos. Nenhum dos entrevistados associou o aumento ou diminuição do custo de vida da região com a instalação da FCA.

Com relação ao valor dos aluguéis, 90,5\% (19) disseram que os valores aumentaram/são mais caros no bairro; $4,75 \%$ (1) disseram ser mais baratos e $4,75 \%$ (1) não souberam informar. Para aqueles que responderam que os valores dos aluguéis aumentaram/são mais caros no bairro, $78,9 \%$ (15) atribuem os altos valores à instalação da Faculdade e a presença de estudantes na região; 10,5\% (2) acreditam que é devido à localização do bairro; $5,3 \%$ (1) disseram que é por abuso dos proprietários dos imóveis e $5,3 \%$ (1) relacionaram os valores com a situação econômica do país.

Os moradores foram questionados se o bairro é violento, para $76,2 \%$ (16) o bairro não é violento e para $23,8 \%$ (5) o bairro é violento. Quanto aos assaltos que ocorrem no bairro, os moradores foram questionados se existe algo que atraia os assaltantes, para $52,4 \%$ (11) a presença da FCA e de estudantes atrai os assaltantes; para $14,3 \%$ (3) não existe nada que atraia os assaltantes; para $14,3 \%$ (3) a venda de drogas no bairro é o que atrai os assaltantes e 19\% (4) não responderam.

Para $33,33 \%$ (7) dos moradores o bairro é barulhento, já para $66,66 \%$ (14) o bairro não é barulhento. Quando questionados se é comum ocorrer festas de estudantes no bairro, $19 \%$ (4) disseram que é comum ocorrer festas; $23,8 \%$ (5) disseram que já ocorreram festas no passado, mas atualmente não são mais realizadas; já para $57,2 \%$ (12) não são/nunca foram realizadas festas de estudantes no bairro.

\section{Conclusão}

$\mathrm{Na}$ percepção da população do entorno, os maiores prejudicados pela instalação da Faculdade de Ciências Aplicadas na região foram os próprios estudantes, pois estes passaram a ter que alugar casas por altos valores e também a sofrer com os furtos e roubos nos bairros do entorno.

Fica evidente a necessidade da formulação de políticas públicas cada vez mais interdisciplinares, intersetoriais e transversais, a fim de tornar a formulação mais completa e com menor incidência de consequências não-intencionais ou não-previstas.

\section{Agradecimentos}

Ao Prof. Álvaro pela oportunidade e ensinamentos. Ao SAE/UNICAMP pelo auxílio financeiro que possibilitou o desenvolvimento desta pesquisa.

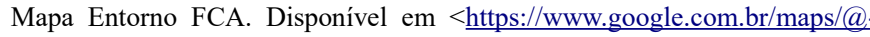
22.5577219,-47.4294382,17z> Acesso em 14/07/2016;

MARCONI, M. A.; LAKATOS, E. M. Fundamentos de metodologia cientifica. 5 ed. São Paulo: Atlas, 2003;

SILVA, Murilo Santos da. Os Impactos da Instalação da Faculdade de Ciências Aplicadas da UNICAMP em Limeira/SP - percepção da população do entorno e demais atores. Paper apresentado no II Encontro Nacional de Políticas Públicas, em fase de publicação nos anais do evento. Araraquara/SP,

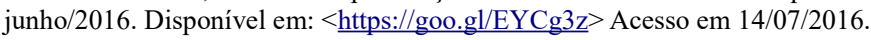

